\title{
MUSICAL BODY OF THE UNIVERSE: THE ONE AND MANY IN AN AMAZONIAN COSMOLOGY
}

\author{
CORPO MUSICAL DO UNIVERSO: UM E VÁRIOS EM UMA COSMOLOGIA \\ AMAZÔNICA
}

Robin M. Wright

\section{Resumo}

Este trabalho explora os significados de "Corpo" e "Espírito" em relação a um dos mais importantes personagens na cosmologia Hohodene, o espírito "Guardião da Doença e da Magia", chamado Kuwai ["Yurupary", em língua geral]. Este Grande Espírito é uma síntese extraordinariamente complexa da visão Hohodene (e de outros Baniwa, povos falantes do Arawak setentrional). Ele é o "coração/ alma" do seu pai, o Criador Nhiaperikuli, o que implica que ele não é um ser material. O corpo de seu "Espírito" é permeado por buracos, por onde a respiração de sua alma produz uma grande variação de sons, melodias e canções. Todos esses sons, eventualmente, se tornaram canções ancestrais primordiais produzidas por flautas; muitos deles referentes a animais primordiais, peixes ou cantos de pássaros intrinsecamente conectados aos valores e processos reproduzidos pela sociedade Hohodene: parentesco vs afins, feitiçaria contra curandeiros, os primeiros antepassados (que ainda não estavam plenamente humanos) e suas relações. De maneira geral, o Corpo-espírito de Kuwai, depois transformado pelo Pai Criador Nhiaperikuli em flautas e trompetes musicais e sacros, pode ser entendido como os meios de reproduzir a "sociedade" e o "universo". Além do mais, este trabalho explora "o corpo musical do universo" dos Hohodene. Som e visão são propositalmente conectados como os principais geradores de vida os quais dão princípio e eternamente reproduzirão o mundo. Em minha interpretação, eu busco desvelar as múltiplas camadas de significados relacionadas a esta figura ao utilizar de exegeses nativas que conectam narrativas,
Abstract

This paper explores the meanings of "Body" and "Spirit" in relation to one of the most important personages in Hohodene cosmology, the spirit "Owner of Sickness and Sorcery", named Kuwai. \{"Yurupary" in general language] This Great Spirit is an extraordinarily complex synthesis of the Hohodene (and other Baniwa, northern Arawak-speaking peoples) worldview. He is the "heart/soul" of his father, the Creator Nhiaperikuli, implying that he was not a material being. His spirit "Body" was full of holes from which the breath of his soul produced a very large range of sounds, melodies, and song. All of these sounds eventually became primordial ancestral songs produced by material flutes; many of them refer to primordial animal, fish, or birdsongs intrinsically connected to core values and processes reproduced in Hohodene society: kinship vs affines, sorcery vs healers, the first ancestors (who were not yet fully human) and their relations. Taken as a whole, the spirit-Body of Kuwai, later transformed by the Creator Father Nhiaperikuli into sacred musical flutes and trumpets, can be understood as the means for reproducing 'society' and the 'universe'. Thus, this paper explores the Hohodene "musical body of the universe". Sound and vision are purposefully connected as the principal life-forces that gave rise to, and will eternally reproduce the world. In my interpretation, I seek to unravel multiple layers of meaning related to this figure by utilizing native exegeses that connect narratives, graphic representations (including petroglyphs), shamanic cures and visions, sacred geography, and sacred chants. I hope to show that Hohodene notions of Self, Cosmos, Ontology, and History are intertwi- 
representações gráficas (incluindo petroglifos), curas xamânicas e visões, geografia sagrada e cantos sacros. Eu espero mostrar que as noções Hohodene de Self, Cosmos, Ontologia e História estão entrelaçadas em uma abrangente multiplicidade de seres vivos em um único material e espiritual "Corpo". O corpo de Kuwai é considerado o corpo do universo, em que os mundos material e espiritual estão intimamente entrelaçados. Assim, as relações com o mundo espiritual, como as relações com o mundo dos brancos, ou as relações com a categoria de estranhos dentro da sociedade (ou seja, os feiticeiros) são igualmente partes da historicidade indígena no sentido mais básico da palavra, que é a reprodução da sociedade e cosmos no tempo e no espaço. Sociedade não consiste apenas em parentelas (neste caso, fratrias exogâmicas), mas também "outros grupos", a alteridade, povos fora do círculo de parentelas. A história sagrada para os Baniwa, como lembrado em narrativas e pinturas rupestres, confunde-se com os processos reais e eventos, tais como relações interétnicas com os brancos, e a história das acusações de feitiçaria que deram origem a movimentos proféticos desde o século XIX.

\section{Palavras-Chave:}

Corpo; Espírito; Universo Musical.

When I began my field research among the Baniwa four decades ago', I was taught about Kuwai by a very elderly shaman, who after explaining to me dozens of times the story of Kuwai, exclaimed one day: "I am Kuwai. You are Kuwai, we all are Kuwai." -one of those beautifully simple yet profound expressions of what humanity is, in the perspective of the Hohodene Baniwa peoples. So what does the phrase mean? It says that we all share similar features of a humanity that came into being at the end of the creative period, and those features are defined by who the spirit Kuwai is.

This is the question I shall explore in this paper. From the discussion, we can understand better indigenous notions of history as dynamic process, consisting of a society's struggle by to reproduce its own identity, materially and spiritually, against ned in an all-encompassing multiplicity of living entities into one material and spiritual "Body". The body of Kuwai is considered the body of the universe, in which the material and spiritual worlds are inextricably interwoven. Thus, relations with the spirit-world, like relations with the world of white men, or relations with the category of outsiders within society (i.e., the sorcerers) are all equally parts of indigenous historicity in the most basic sense of the word, that is, the reproduction of society and cosmos in time and space. Society consists not only of kingroups, (in this case, exogamous phratries), but also, "other groups", alterity, peoples outside the circle of kingroups. Sacred history for the Baniwa, as remembered in narratives and petroglyphs, is intertwined with actual processes and events such as interethnic relations with the Whites, and the history of sorcery accusations which have given rise to prophet movements ever since the 19th century.

\section{Keywords:}

Body; Spirit; Musical Universe.

threats from the external and potentially enemy world to change and destroy that identity. Thus, Baniwa narratives about the present-day, and about their historic ancestors are couched in a kind of discourse that recalls the primordial world of Kuwai, primordial enemy sorcerer-tribes, principally affinal.

The Northwest Amazon region has been compared to a "Tower of Babel" because of its linguistic diversity. The more than 22 ethnic groups who consider themselves as distinct socio-political units are grouped by linguists into three major language families: northern Arawak, eastern Tukano, and Maku. Despite their linguistic diversity, all peoples share in a number of cultural patterns and institutions, among them the sacred rites of passage involving the ancestral flutes and trumpets 
which are considered to be the Body of the first ancestral being from which came the ancestors of all peoples. These flutes and trumpets are considered extremely sacred, for which reason they are generally hidden, wrapped in leaf bundles and buried along the riverbanks in places that only the adult men know. The traditions related to Kuwai are for that reason highly relevant for understanding the ongoing interconnectedness amongst widely separated communities, located a day or more by canoe from each other by canoe- (at least when I lived there).

I should clarify that the present-day cultural situation among the Baniwa is that most of them are evangelical, who generally abandoned the Kuwai traditions in the 1950s and '60s when they converted to fundamentalist evangelicalism introduced by the North American New Tribes Mission. Over the last few years, however, there has been a notable effort on the part of indigenous organizations and government agencies in Colombia and Brazil to support the revitalization of this cultural heritage ${ }^{2}$ (the knowledge, beliefs, and practices associated with the ancestral flutes and trumpets) through recognition by the UNESCO in the year 2010. There have been numerous experiments and projects supported by humanitarian and charitable foundations over the past 20 years that have to do with the revitalization of institutions suppressed by Catholic and Protestant evangelical missionaries. My impression is that there are still divisions between those communities who continue the traditions, and those who abandoned them long ago, but that the whole area is engaged in "cultural transformation and/or revitalization."

The first part of this paper shows how the body of the great spirit of Kuwai is a singular entity comprised of multiple parts expressed primarily through sonic imagery and formal, ceremonial dialogue that comprises the dynamics of the universe. Through the inter-relations amongst the parts flow primordial life-principles bestowed or 'left' by the creator deities.

The arguments in this paper find strong theoretical support in the recent ethnological interpretations of subjectivity and materiality, in Santos-Granero's collection (2009) The Occult Side of Things as well as Pitarch's elucidating discussion of multiple souls and the construction of historical identity in The Jaguar and the Priest (2013). Many of the points raised here were also developed in my Mysteries of the Jaguar shamans (2013); however, new insights inspired by the works mentioned have led me to see a deeper level of connectedness between material and spiritual worlds in the Hohodene universe.

One of the features of the sacredness embodied in the ancestral flutes and trumpets today is a strong prohibition against the women and the uninitiated from seeing them, or knowing what they look like. In contemplating the strong taboo which still exists in traditionalist communities, I've come to the conclusion that much of what has been said regarding male dominance and symbolic violence enacted in the ceremonies of the flutes has been misguided; consequently, outsiders who constantly try to break the secrecy law are doing a tremendous harm to the identity of the various sibs/ phratries $^{3}$ when they insist on revealing the flutes and trumpets to those who cannot see them. For there are indelible links between the creation cycles and the prohibition itself.

Among northern Arawakan societies, 'phratric exogamy' is imperative to social relations; i.e., women marry out of the phratry into which they were born and into a phratry with whom their families wish to establish or continue alliances. The taboo on outsider women seeing the sacred ancestral flutes of their husbands' phratry has little if anything to do with a supposed dread of 'incest' (which does not exist in Baniwa mythic narratives) and more with the potential dangers of an "external Other" gaining the knowledge of an "insider" and discovering the source of the phratry's ancestral power. This represents a great risk expressed in the mythic cycles of the primordial world, in which the Creator and his kin are always opposed to "other peoples", non-kin, affines, animal tribes, generally the enemy tree-animals who are portrayed as the primordial sorcerers.

All his sacred body parts together emit powerful music, sounds of the primordial spirit-world. This primordial universe was made by the knowledge and power, thought and prayer, of the creator father of Kuwai, who sent his knowledge into the "closed" body of the first woman Amaru. When her body was opened for birth, out came all shamanic power and all the pieces of Kuwai. The story of this emergence is inscribed in the boulders of the place called Hipana, where there is a large, 
circular hole in the earth from which the original sun ascended to the sky before time existed. From that same hole, the primordial ancestors likewise emerged. Thus the story of Kuwai is a critical transitional narrative between the pre-temporal world of the beginning and the world when time, and the instruments for reproducing society and the entire universe, are solidified into fixed form. Hence, in the narrative, the world expands and contracts, opens and closes, until the power of the Sun-child is absorbed into the first humanity, and his spirit ascended to the "other world" of the sky.

In the very first cycle of creation narratives, the animal-tribes steal poison from the Creator and with it, they kill the Creator's younger brother. Thus, death entered the world, eliminating definitively the possibility of humans being like the immortal primordial beings. The ensuing struggle over sorcery in the narratives is constant and without resolution; it is equivalent in present-day society to the struggles between the jaguar shamans/prophets and the sorcerers (who have animal-like features attributed to them by shamans). The implications of this struggle are that women who come from Other tribes and marry into the Hohodene phratry bring with them the potential threat of treachery. They are, for that reason, prohibited from knowing the "secrets of the flutes and trumpets." It is clear, however, that women of the same sib probably do know about their sib's primal ancestry, and what the name of their phratric flute ancestor is and what sounds it makes (This is taught in the sib's emergence story). But they are prohibited from seeing them - as are the initiated boys who actually do see the flutes and trumpets.

The women are, according to the narrative traditions intermediaries with the external world (affinal, potentially affinal) just as shamans are intermediaries with the Other World of the great spirits. Both therefore are locked in a kind of complementary opposition that is the moving force or dynamic of reciprocity and exchange, implying both marriage and sorcery. Ancestral power embodied in the actual flutes and trumpets, known collectively as "Kuwar", thus distinguishes one phratry's collective identity from another. Since the law of exogamy (marital exchange) is a centrifugal force through which the external world (in-marrying women, non-indigenous peoples) penetrates the internal world of the sib/phratry, there is an ex- treme taboo on showing the flutes to the women, which we interpret to be an adaptive mechanism to preserve intact the internal continuity of phratric identity against the threatening powers which outsiders represent. This, we argue, underlies statements made by important shamans about not giving up the traditions, for then the enemy will take over and the people will be ruined. (Wright, 2013, Chapter 1)

\section{"With Shame He Comes": The Hidden Anomaly}

In the sacred narrative of Kuwai, as soon as the child was born, the men hustled him away and hid him in the forest because of its grotesque appearance, strange and extremely violent acts - a mouth full of jaguar teeth, a placenta that had the form of a poisonous stingray, the child's uncontrollable thirst for milk. The Creator Sun father was astonished that his child had such a strange form and yet, paradoxically, the child emitted melodious sounds from various of its body-parts. The child was so "ashamed" of its strange appearance, it is said, he violently sucked dry the breast of a sloth 'wetnurse'. Fearing that his child would wreak havoc in the world, the Creator sent him far away to live hidden in another place for a long time. Kuwai was his child, the "soul of his father the primordial Sun", produced by the shamanic knowledge and power of his father but he also was the spirit of sorcery and sickness.

One 98-year old jaguar shaman narrated the birth of Kuwai as follows:

\begin{abstract}
"At Kuwai's birth, he was hidden away. Kuwai was taken to Kuwai ifakahruakan. (place where he was nursed by a sloth mother) The men showed Amaru [the mother] a stingray, called, "niamaru", saying that the only thing that was born was just the stingray-placenta. Before Kuwai was born, his mother Amaru went looking for a place to give birth. She went to the Uaupés River, later the Içana River - at the place called Tsépan - and she lay down there. Later, she went to Puwedali, on the Ucaiali (Uaupes) River, and went to lie down there.. Later, Uapui, and she stayed there. After Kuwai was born, he was hidden from her at a place downriver. At Dumalipekwa, three places below. Thuruapekwa, Thiripidapekwa. Nhiãpirikuli went after him."
\end{abstract}

The child's mother "knew" that the men had taken her child away, and she wanted her child back. Throughout the story, the men constantly deceive the women fearing that they would take the dan- 
gerous powers embodied in Kuwai away, which would leave them helpless to defend their identities from outsiders. This dread of being without an identity and inability to do anything at all is the basis for the secrecy ideology. According to the narrative, when the women did steal the material body of Kuwai, as the flutes and trumpets, the world became chaotic, noisy, disordered, as a wild storm of poison darts shot out of the flute mouths forcing the men to retreat and hide. Once the Creator succeeded in taking back the flutes, he adorned them, and their melodious sounds, embodying the true attributes of 'personhood' were reproduced, so he then declared: "now people can take these and blow them". Thus, the women today "do not know" how the instruments actually look or sound.

In other words, the whole process of reproducing new generations of adults, and by extension, the entire universe, was complete when the Creator succeeded in replicating the melodic voice of his own child -the Creator breathed life into his son's transformed material body, in the flutes and trumpets made out of paxiuba palmwood, strong vines, and treebark. The powerful feather of the hawk Haawa, when attached to the bodies of the flutes, opened up their sonic power emitting the "one and only" (hnahawaakatsa) true sounds of Kuwai, empowering all material forms and shapes with their creative 'burst-of-breath' (Hill \& Chaumeil, 2013).

Kuwai embodies both a concept of Multiple beings-in-One, and One Being-in-Multiplicity that is the Universe. The multiplicity is made up of the material bodies (flutes and trumpets) of Kuwaiancestral spirits, each of which is very different, as are the melodic sounds and noises they produce. Each ancestral spirit has its own 'body', but is also a part (arm, leg, claw) of the universal Body that is Kuwai.

In the following discussion, I seek to show systematically how all the sacred flutes and trumpets, when joined together, form the spiritual and material Body of Kuwai. By combining all the features of the individual instruments together, we arrive at a deeper understanding of the relation between spirit and matter in the Hohodene universe. For each instrument, I ask: what cultural categories are being focused ? What view of 'the world' is communicated through the body parts and soun- ds that Kuwai makes?

The drawing above was made by a shaman's apprentice, under the guidance of the master shaman Manuel da Silva. Kuwai has another sacred name, "the bicho", the Animal. Each body part of Kuwai has a name and a melody, associated with primal land-living animals, birds, tree-living animals, fish, and especially, the jaguar. All of these animal parts together comprise his Body. Stories about many, if not all of these animal/bird/fish beings can be found in mythic narratives that explain some defining feature of these animals. These mythic narratives have to do with the primordial world, in which central categories of cultural and social life are being placed in relation to each other. It is as though the sacred narratives provide a conceptual framework for understanding the dynamics of the cosmos. Shamanic hawk spirits, two parts of Kuwai's spirit-body, are opposed to tree-living animals, considered in the stories as 'enemy' sorcerer tribes, just as, today, shamans are opposed to the sorcerers.

The black sloth is one of Kuwai's avatars, but there are many other avatars of Kuwai: as a monstrous ogre (Inyaime), a spirit of the dead, or as a big-bellied monkey. All of these images are in the environment that surround the Baniwa. The Hohodene Baniwa often remember the details of the stories as they travel the rivers and note along the way places that are the dwelling-places of spirits. So, the spirit of Kuwai or what he left in the world is found throughout the environment, and in the shamans' chants of initiation, highly codified 'thought-voyages' that name the spirit-names of every place in the known world.

This is because Kuwai's music created the world, that is, made it open up (expand) from its primordial, miniature size, to the huge territory and world that the Baniwa know today. There are, today, Kuwainai, ancestral spirits throughout the world, but they are hidden and can only be manipulated by the men.

Kuwai's body and his knowledge are also found in sorcery because, upon the death by fire of the original Kuwai, his Body transformed into all species of insects, spirits and plants that may give humans sickness. For this reason, the shaman is the principal actor in Baniwa society who can ward off their danger. The evangelicals, it is said, believe that the "demon-spirit Inyaime" is everywhere", which is lu- 
Figura 1: Kuwai - Idzamikathe Iminali: The Keeper of Sicknesses (drawing by a shaman's apprentice, Uapui Cachoeira, Rio Aiary, 2010)

dicrous from the shamans' viewpoint, a simplistic view of classifying the diversity of the spirit-world in which they live.

\section{Inside and Outside, Open and Closed: Duality in Kuwai's Body}

There are other ways of representing this being that complement the one above; especially important for our interpretation here is one which was made by a Hohodene jaguar shaman Luiz Gomes, a distant cousin of Manuel da Silva. The anthropologist/linguist Dr. Omar González-Ñánez who has worked for 4 decades among northern Arawak-speaking peoples especially in Venezuela, requested that Luiz draw Kuwai, also known as Kuwai-ka-Wamundana, the "Guardian of Sorcery and Sickness", a sacred name referring to Kuwai's principal animal soul identity as "the black sloth shadow-soul."(see Fig. 2, p. 134 and Ch. 4 of my book). The main differences with Figure 1 are (1) the designations of the kinds of sicknesses associated with each part of Kuwai's body, and (2) the apertures along the outer boundaries of his body. Each of these apertures emitted a certain melody, when Kuwai was alive, of bird, fish, or animal-song. After Kuwai's fiery death, the parts of his body corresponding to the apertures became flutes or trumpets cut from a giant paxiuba palmtree that burst from the earth at the place of his burning.

All Baniwa ancestral flutes and trumpets are considered to be parts of the Body of Kuwail. Most of them come in pairs, replicating the long bones of Kuwai's body. The exceptions are the single flute called Mulitu, said to be his penis; and the triple flutes called Waliadoa, 'Young Sister initiate', corresponding to three claws of one paw.

Each pair has a sacred name that corresponds to a primordial, ancestral being, one of many whose bodies had shapes drawn in the petroglyphs as long flutes or trumpets. Several of these ancestral beings had appendages such as wings, legs and arms, corresponding to the long bones, claws, and appendages of "Kuwai's Body". Considered altogether, the graphic representations of these primordial beings, chiseled in the boulders of many rapids in the Northwest Amazon, comprise a cultural memory of the primordial world, how it came into being, and the world-changing events that made the contemporary world that people live in the way it is. (Wright, 2013; Xavier Leal, 2008; Gonzalez-Ñánez, 2006) This cultural memory can be understood as a social history as well, in the most essential meaning of the term as a view of how society is reproduced over time (Turner, in Hill, 1988). For, the elements comprising Kuwai's body orient the Hohodene today as to who their kin and allies are, and who their affines and enemies are.

The Body of Kuwai in the drawing below consists: firstly, of a complex combination of sicknesses and remedies concentrated in both a central internal axis inside and the external covering of the body; and secondly, numerous holes in his body 
that produce a variety of animal sounds that later became material ancestral flutes and trumpets of existing phratries, each defining central features of Hohodene Personhood. To understand this, I shall analyze the elements of sickness and sorcery in Kuwai's Body first, followed by the notions of ancestrality and growth.

The body parts of Kuwai considered to be sources of both sicknesses and remedies are: (a) the crown of his head (Kuwai ithipale), (b) throat (liweda) $\quad$ (c) the heart (ikaale) and (d) the umbilicus (hliepuhle). All of these are key points of soul passage, i.e., of entry and exit of human souls at birth, coming-of-age, sickness, and death, thereby linking Kuwai to the knowledge and powers of the priestly chanters, sorcerer and the shaman.

Around the crownareclustered various material forms of sicknesses that shamans attribute to Kuwai: hair, said to be tucum fibre, from the moriche palm (Mauritia flexuosa), also known as buriti ${ }^{5}$, associated with sicknesses produced by a sorcerer's poison, manhene; a white stone "that gives headaches"; a snake that produces a painful sickness called hiviathi.

The "heart/soul" concentrates in the form of darts, four major sicknesses that the shaman learn how to cure first during his/her apprenticeship: the yoopinai, spirits of the environment; the walama, darts that come from shamans, whether human or not $^{6}$; the haikuita, pieces of wood; and sicknesses of the blood, such as hemorrhaging.

Finally, the umbilicus which is said to contain the most powerful remedy (tápe) against sorcerers' poison - "our umbilicus", the connection between the first ancestors of the phratries and all their descendants. The umbilical cord constitutes the very first 'soul' of every person which enters a body in This World at birth. It is also the first of several souls to leave a person at death and return to the Other World, where all the souls of the deceased from the beginning of time are located. For the shaman Luiz, it is from the umbilicus of Kuwai that the shaman takes out medicine for ifiukali, a grave sickness of the digestive tract that makes one thin, anemic, wasted away. This sickness, like all others mentioned, has its origins in the stories?

The internal axis of sickness and health, as we mi- ght call it, in Kuwai's body consists of the major sources of sicknesses, which are nevertheless the sources of remedies that shamans can use to cure the same sickness. This double-sided feature of the powers contained in Kuwai's body is as essential to understand as it is to know how each type of sickness and remedy came into being and why.

As one elderly shaman narrator explained,

\begin{abstract}
"After Kuwai had gone away, Nhiaperikuli filled a pot with manhene (poison) and then, a friend of his drank the plant poisons called hfero, lixupana. He began to have diarrheia. Nhiaperikuli took the ceramic pot to his house and left it there in order to keep it from others' wanting it. He ordered his people the Kuwaikere ${ }^{8}$ to make sure that no other people could come and take away the poison. The Eenunai [tribe of tree-living animals], however, succeded in tricking them and stole the poison from Nhiaperikuli. Eenunai iketsuali ikurumanhene." (Matteo P., 1998)
\end{abstract}

The fur (Kuwai liidzu) of his body is considered one of the most potent types of poison which a true shaman in his trance journeys to the "Other World"(Apakwa hekwapi) where Kuwailives today, must obtain from the Body of Kuwai in order to cure a patient in "This World"(Hliekwapi).

Kuwai's body was covered by hair or fur, which seems like a paradoxical mixing/merging of the categories 'open' and 'closed' used to describe his body and, as we shall see, aspects of the universe. Similar to the sloth's (wamu) body, which harbors innumerable kinds of fungae that live symbiotically in its fur, Kuwai's fur was full of poison. Similar also to the sloth's habits, Kuwai was most of the time "closed", exercising great control over his digestive orifices, which is appropriate for the fasting period he imposed on initiates. When his body 'opens', it is either to emit creative sounds, or to allow poisonous fluids to fall like rain on the earth. (Thus we can say that the fur that covers Kuwai's body is what provokes deathly openness in the victims of sorcery; while the openness of Kuwai's body (the holes that emit music) require the seclusion of humans from the social world.)

It is important to understand how these sound emissions are modulated throughout the narrative corresponding to various levels of meaning (e.g., a melody sung in harmony vs a chaotic bellowing of sounds; a diet of ripe forest-fruits vs a cannibalistic devouring of flesh). ${ }^{9}$ 


\section{Viscera, Body Fluids and Their Significance}

Kuwai's viscera (specifically, his liver) contained poison that was absorbed by certain plants after his death; these plants have the shape of a liver ${ }^{10}$. Larvae associated with rotten wood are said to be the "bile of Kuwai"(lidanhe), part of his poisonous animal-form associated with rot. However, in Kuwai's way of seeing the world, the larvae are "his heart-soul" (suggesting life-in-rot), while to humans, they are the bile that spoils the meat of freshly-killed game animals.

One of the most important fluids of Kuwai's body is his blood which is identified by the shamans as "pariká" (dzaato), the psychoactive that shamans inhale in its dried out form as snuff in order to "die" (enter into trance) and return to the Other World of the deities and spirits; this dried-out "blood" nourishes the shaman's own heart/soul, ikaale, which means both the material organ and the spiritual source of life-supporting energy in the blood that can be vital to cures.

Kuwai's saliva, liahnuma, likewise can be both a creative, seminal fluid which regenerates the physical world, but can also be used in sorcery. One example of liahnuma in the material world are all the vines that flower at the time of the Pleiades, called Thameali- wape that drop from the trees. These came into being when - in the narrative Kuwai "becomes other", "dies" (loses consciousness) and transforms into a monstrous ogre. At that moment, saliva pours out from the holes of his body followed by a powerful roar of sound. This moment in the narrative can be understood as the end of the annual cycle and the beginning of a new cycle. The universe undergoes a major transition powerfully represented in the narrative as the catastrophic 'death' of Kuwai, followed by his immediate transformation into a monstrous sorcerer that devoured three young initiates. The vines are the visible materialization of this dramatic death of the great spirit and transformation into a monstrous Other demonic being.

An excessive loss of this life-giving fluid, saliva, is one feature of the most dreaded ailments an initiate could get, a wasting away sickness, purakali, characterized by constant dribbling of sali$\mathrm{va}$, along with the transformation of the initiate's body parts into animal, or plant parts. It is the dissolution of the person into a grotesque assemblage of deformed plant and animal parts.(see my article, 1993, "Pursuing the Spirits" for further discussion of this condition) Purakali is a form of Other-becoming that occurs at seasonal changes, for example, from dry to wet, or the result of not obeying restrictions at these critical moments of time. When this occurs, a powerful reaction from the "Owner of Sicknesses" can be expected against the initiate, just as happened in primordial times.

The 'other side' of liahnuma can also be seen today in acts of sorcery, where a sorcerer will cast a spell by leaving his saliva along the trail where a victim will walk. Sorcery produces a condition of physical, "open-ness" in its victims in which an excess of fluids is involuntarily expelled from the body (vomiting, diarreia).

Kuwai embodies "his father's soul" but can transform into various spirit-Others which are considered to belong to groups of "enemies", (-puunda): Inyaime", an extremely dangerous, cannibalistic ogre, a transformative spirit of death, known as the "Other Kuwal"; Yoopinai, the sickness-transmitting spirits of the forest, rivers and riverbanks; and the White Man, yalanawinai, who, it is believed, was generated from grubs of a rotten, slain enemy Anaconda.

The "heart-soul" of a sorcerer today is said to become inyaime, a demonic 'other', non-human, without a soul. The kind of spirits called yoopinai have bodies of plants, bushes or shrubs, as well as the countless kinds of insects, bugs, and spiders which can be invoked to give sickness and pain to humans, or themselves put sickness on humans should the latter invade their spaces (outcroppings of rocks, along the riverbanks).

The yoopinai came into being ("were born") from Kuwai's ashes at the moment of his spirit's departure from This World. Most importantly, at the moment of his burning in fire, he lets loose from his body all of these spirits which then spread all throughout the world. Kuwai embodied all sickness and sorcery; he is their "owner". His fur, it is said, "ran and entered the body of the black sloth", Kuwai's shadow-soul today (Kuwai idanamini wamu).

If an initiate breaks the restrictions imposed on all 
those who are participating in the Kuwai rites, it is believed that a catastrophe will take place. For, the other side of Kuwai is his power to destroy life, through violence, chaotic and loud sounds like the crashing of thunder, and by unleashing sickness and diseases throughout the world.

\section{Kuwai, Cultural Transmission and Growth}

The story of Kuwairelates how this multiple-in-one being came into the world and develops through an entire life-cycle: conception, pre-birth, baby/ infant, adult, old man, and post-mortem body/ soul. During the story, an initiate is instructed on the multiple relations between humans and Other beings. Kuwai was eventually 'killed' at the end of the first initiation rite when his father pushes him into an enormous fire and, following this, his Body became an enormous paxiuba palmtree which his father then measured, cut down, and produced ancestral trumpets/flutes. These are the first ancestors of the phratries, or Kuwainai, but they did not have bodies like humans today, nor did they perform any actions except that of going to live in places of the first world where their descendants may still live today. These first ancestors constituted the first material and spiritual links to the land.

At a later point, the first phratric ancestors with real human bodies came into being, and these shared some of the qualities and imperfections of the primordial beings, deities and great spirits. They created things, made mistakes, or fought amongst themselves. The names of these first ancestors are remembered and form part of the stock of ancestral names bestowed upon newborns today.

Following the first ancestors, at a much later point in time, the "historical" ancestors are remembered for specific events and processes significant to the social reproduction of the phratry, and to the Baniwa/Kuripako-speaking peoples as a whole. For example, the stories relate the first contact with the White people, and struggles to survive epidemic diseases and forced relocation.

Thus we may say that the knowledge of Kuwai constitutes the cultural memory of the phratries, which includes all of the life phases and transitions that people will pass through, as well as the principal processes in the drama of cosmic history. The more recent historical ancestors are recognized for their courage in overcoming enemies, for making alliances and guaranteeing the material prosperity of the phratry, and for founding actual settlements in their phratric territory. The historical 'wise men', or savants (prophets) comprise a special category of ancestors, the jaguar shaman protectors of humanity against sorcerers. There are thus several continuous links that can be made between primordial and historic past, and the present which it is the responsibilities of the elders to maintain unbroken.

The meanings of the body parts of Kuwai directly refer to categories that are always engaged in their understanding of history, society in history: besides their being body parts of Kuwai' primordial body, they represent the nature and qualities of the collective "Self" (sibs and phratries), and of collective "Others" or alterity, as well.

Ancestral powers of fertility, reproduction and growth, coupled with the catastrophic powers of sickness and sorcery, are embodied in the sacred flutes and trumpets. In this world, everywhere there are ancestral souls (kuwainal), there will also be spirits of enemies, sickness and sorcery. The danger of losing the connection, breaking the link with the primordial past cannot be understated. For the Hohodene, without their traditions, they believe they would succumb to the enemy others. This is how many Baniwa understood the catastrophe produced by evangelical conversion in the 1950s, and how Manuel da Silva believes will happen if the children today forget their ways de to the new technology they are being introduced to, and access to the internet world..

In the performance of initiation rites today, the sounds of the flutes and trumpets along with the whips that were part of Kuwai's body are what make the initiates and fruit-bearing palm trees grow. The whips break open the initiates' skin allowing the sounds to penetrate the initiates' heart/ souls. With these sounds, there is growth and expansion; with Kuwai's whips, plus the 'fire' of sacred pepper, the initiates 'dry out', that is, they become immune to the potentially dangerous ancestral spirits (Kuwainal) ${ }^{12}$. Initiates are taught to control bodily needs by fasting ("drying out") and to become fully cultural beings by recognizing and experiencing the music of the sacred. In the story, Kuwaionly revealed his music and power in small doses. When he does reveal his full power, 
it is with the mediation of his father's presence; without that mediation, the initiates succumb to their bodily desires, provoking a catastrophe that ends in the disastrous devouring of three out of four initiates called Malinali-ieni.

When Kuwai's melodies are played, today as in the beginning times, they are always accompanied by the sounds of whips slashing the bodies of the participants. In resisting the pain of the whips (not demonstrating pain through crying or even flinching), all life grows "with force" (quickly) and strength. This is why the men play the flutes and trumpets during the time of the ripening of the forest-fruits, at the base of the fruit-trees - in order to make them grow in abundance, as food for the initiates and whoever is "seeing Kuwai" (Hugh-Jones, 1989, P. Maia, 2008; Vutova, 2013 ).

\section{Sacred Sounds and Growth}

The apertures, "holes", in Kuwai's body were thus externalized and materialized after his sacrifice in the great fire. All the apertures materialized into a single enormous palmtree, the paxiuba, that connected This World and the Other World where Kuwai's spirit had ascended and remains today. The sacred flutes were then measured and cut from this single source; once the tree was broken into pieces and fell to the ground, the Creator fashioned them in such a way as to replicate the melodic sounds of the original Body of Kuwai. His thorax became the great trumpets that bellow out the "Jaguar Bone" song that "opened up" the world, making it expand like a balloon to its present-day size. ${ }^{13}$

The shaman's drawing below positions the apertures in Kuwai's body in such a way as to indicate an order, on both sides of the body, of named flutes and trumpets (each stick or oblong shape representing a long flute). From the meanings attributed to each of the flutes, we come to understand (1) what features or attributes of primordial ancestrality are most significant, (2) what aspects of the primordial world and its powers were transmitted by the Creator to all future generations, and especially (3) the vital importance of transmitting cultural memory.

These meanings altogether constitute the sha- mans' understanding of the Universe and its dynamic processes of reproduction. By "reproduction", I mean not merely biological reproduction, nor the physical "body" in the narrow sense which Reichel-Dolmatoff gives to the flutes $(1995,1996)$. For, besides their being parts of Kuwai's primordial Body, they represent the nature and qualities of the Person, of collectivities or the collective "Self" (sibs and phratries), and of collective "Others".

\section{Kuwai-ka Wamundana: By Parts}

What I shall now do is demonstrate how each of the pairs of sacred flutes and trumpets refers to an attribute of Personhood, in both individual and collective senses of ancestrality, as well as attributes of Alterity. The inter-relations of the parts are articulated through transformative processes of 'becoming Other'. This becoming Other is effected by externalizing and materializing that which is internal and powerful, or by internalizing powerful meanings that are imbued in materially external forms.

Kuwai's Body may be divided into four parts: left and right sides, upper and lower parts. Internal and external parts of the Body constitute the linkages embodied in Kuwai between collective Self-identity of the phratry with attributes of Alterity.

We begin with the left side where the following figures (holes, ancestral flutes) are situated:

1. Maaliawa. The drawing below comes from a petroglyph which displays the bodies of 2 flutes in the shape of 2 triangles connected together at their mouths, with a pair of "wings" and stick shapes that are the appendages of the "White Heron", Maali. The entire shape corresponds to the body of the ancestral being Maaliawali, "Young White Heron", which corresponds to the first two fingers of Kuwai's paw and is always the first pair of sacred flutes that dance in the initiation ritual procession:

The name Maaliawalirecalls the primordial initiates of the story, for they are named Maalinali-ienipe. The first pair of long flutes Maaliawali mimics the sound of a rattle being shaken followed by a high-pitched song of a white heron in flight "." Tsatsatsa, Tseytsemtseytsem." 


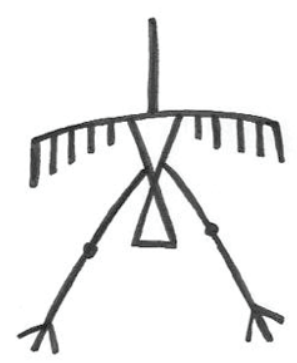

Figure 2: Maaliawali

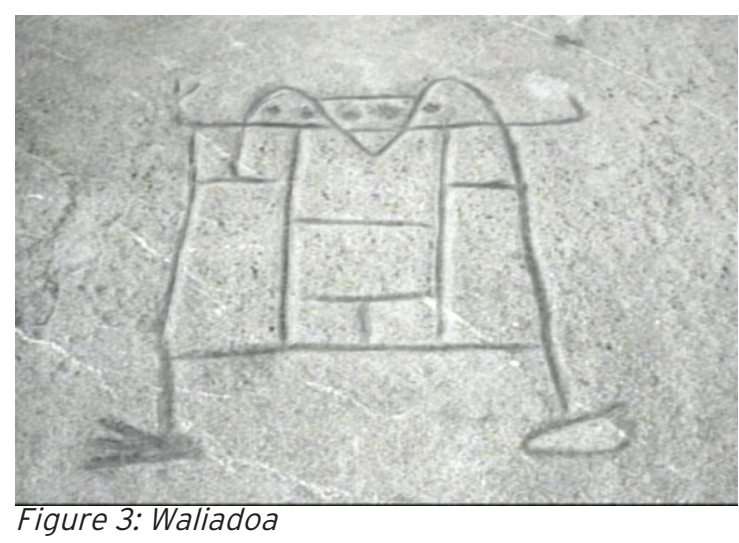

(petroglyph at Ejnipan, Içana River)
2. Waliadoa: a group of three long flutes meaning "Young Sister". In the story, Waliadoa is the first daughter initiated by the first woman Amaru. "Young Sister" is the female partner of Maaliawa, corresponding to the ritual relations of kamaratakan, "like a marriage" the Hohodene say. For, evidently the meaning of the first 2 pairs is related to the category of 'marital relations', conceived of as an exchange.

The body of Waliadoa is drawn in the petroglyphs at Ejnipan (Jandu Rapids) where it is believed the first initiation rite took place, showing a complex form (Fig. 3 ). The body of Waliadoa is sectioned in three parts, corresponding to 3 long flutes, each of which is marked distinctively, perhaps corresponding to the parts of each material flute: the first on the left is sectioned in 3 , while on the right is in 2, and the middle in 4 parts. The head portions of each flute comprise a single head with sockets for 2 eyes and 2 ears.

The three ancestral flutes of Waliadoa correspond to the thumb, index finger, and middle finger of Kuwai's left hand.. They sing a sad melody which consists of three distinct phrases; "'"Eeeteytumdeeee Nupita'mta'mdeee Nupita'mta'mdee" sung in such a way as to equalize or balance the couplet- rising at the end of the first, and descending at the end of the second. The word "nupita" may signify "I weep, I weep". Kuwai's tears are said to be the rains, the time for scheduling the initiation rites.

It is said that, when Kuwaicame into the world, he wept at his own grotesque shape: with the teeth of a jaguar, with holes all over his body, consisting of multiple parts all somehow integrated into one being. He was ashamed (-paymaka) and his father astonished at the strangeness of his body. His father sent him away to the forest and then to the sky. He (Kuwal) was not wanted except by his mother whom the men tricked into thinking that nothing had been born except a stingray placenta. Kuwai became an outsider because of his dangerous powers, but the idea behind the Creator bringing him into being was to be able to transmit all the knowledge he had about shamans, sorcery, and how the world is.

3. Mulitu the Frog: The small figure in the center of the petroglyphs at Ejnipan (Jandu Rapids) is the frog Mulitu, said to be Kuwai's penis, which is the only flute played singly. The single toot "MuU" mimics the song of the frog. (see Hill, 1993, for a discussion of this flute and correlation with ecological cycles). It is said that this single short-flute responds to womens' questions about the sex of their yet-to-be-born babies.

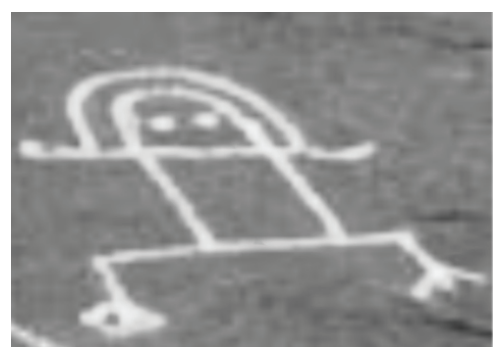

Figure 4: Mulitu (Frog)

4. White Monkey, Halu and the Eenunari: The fourth song is of "White Monkey", Halu (Cebus gracilis Spix) a pair of long flutes coinciding with Kuwai's arms. The White Monkey is one of several tree-living animals whose sounds are parts of Kuwai's body. The White Monkey's song is a high-pitched "Wa wa wa wa wa wa wa wa' followed by the low flute 
refrain " $t e^{\prime} m$ te'm", like a musical dialogue between the two flutes.

There are several other furry tree animals that comprise the body of Kuwai-ka Wamundana : "Tchichi"(Acary, Pithecia Ouakary) and "ipeku"(night monkey, or owl monkey), both of which are considered as very powerful omens of impending death. In one of the stories, the Dzawikwapa was the original ancestor and primary chief of all the tree-living animals. These all belonged to different "Houses" of tribes called collectively the "Eenunai" (Eenu = sky, thunder). Today, they exist no more as tribes with a single chief.

They were primordial sorcerers, among the Creator's principal enemies. The Night Monkey ipeku especially is considered a descendant of the Dzawikwapa, a harbinger of death, an omen if the monkey appears at dusk singing in the trees or sitting on the ground at the outskirts of a village. Kuwai's animal avatar (-ndana, 'shadow') is the "Black Sloth", Wamu, whi$c h$ is the primal animal "guardian of sorcery" (manhene iminali). The furry coats of the Black Sloth and its 'helper', Tchitamali, the "White Sloth", are filled with poison, manhene, which came directly from Kuwai's fur as it burned in the Great Fire that "killed" [i.e., marked the end of,] Kuwai's passage from This World. As one elderly narrator and jaguar-shaman, Matteo, recounted:
"Tchitamali thádua is the mother of the chief of poison. Tchitamali is Kuwai's pet ( ipira). Uamu is Kuwai's pet (ipira). In the story of Mawirikuli, linupa (the stench of the dead that brings on sickness) began. In the end, Mawerikuli went to 'Paradise.' The dead arises, is beautiful, for his/her place, lidzakalekwa, in Pa- radise has already been prepared, in the city of the dead. His/her body has become all White. Nhiãpirikuli wrapped up the manhene that he recovered in a leaf bundle, and threw it on top of a range of hills in Venezuela to keep it guarded." (Fieldnotes. MP -01/2001)

The Eenunai lost their overall primordial unity, after the 'death' of one of their chiefs, Witháferi, who lived inside a sieve and was carried around by two land 'animal'-helpers, the anteater and the paca, a rodent. (see illustration below) As the stories tell, the Eenunai and Itchirinai (mostly ground animals such as Tapir, Anteater), and the Umawa- linai (aquatic spirits which came into existence with the killing of the primordial Anaconda) were affines and enemies of the Creator who constantly plotted to "kill and eat" him by predatory sorcery.

The Creator outsmarted them for the most part by spying on them, preparing superior traps, undergoing transformations, and other artifices; but they caused enough damage as to have killed one of his younger brothers, and almost "killed off" all of the Creator's people, forcing the Creator to burn the entire world and then flood it, which made the enemy spirits flee to the mountaintops and the deep, interior of the forest and rivers. Drawings produced by shaman apprentices in 2010, at my request, illustrate the corporeal anomalies of many of these spirits (e.g., Long Arm), the Umawalinai or aquatic spirits;), many of them being predators of humans. Others are harmless and often serve as auxiliaries to the shaman in his quest to retrieve the souls of the sic.

5. Jaguar Bone, Dzauinaapa is the thorax of Kuwai, or ribcage, iwarudali, the longest and most powerful of the trumpets (botutos) that propitiate transformation in whomever or whatever the Jaguar Bone song is intended to change.. In the narrative and the drawing of Kuwai-ka-Wamundana reproduced below, the 2 trumpets are contrasted with the wasp sound (Aini), produced by play instruments made by the first children initiates, and which were considered to be a "false kuwai, nonsense". Kuwai himself contrasted these buzzing wasp flute imitations of the children with the truly powerful sound of Jaguar Bone that made the world grow and culture be reproduced.

\section{Phratric Ancestors: Hohodene and Walipere- -dakenai.}

Among the more powerful pairs of ttrumpets are the first ancestors of two major phratries of the Baniwa peoples. One pair, Thuwiri, the japu bird, is said to be the Hohodene first ancestor; the other pair, whose name is almost a homonym ( Thuwa) is the first animal ancestor of the Walipere-dakenai phratry, whose name refers to a 'woodpecker'. These phratric bird ancestral trumpets are as prominent in the initiation ritual processions as the "Jaguar Bone" trumpets, and 


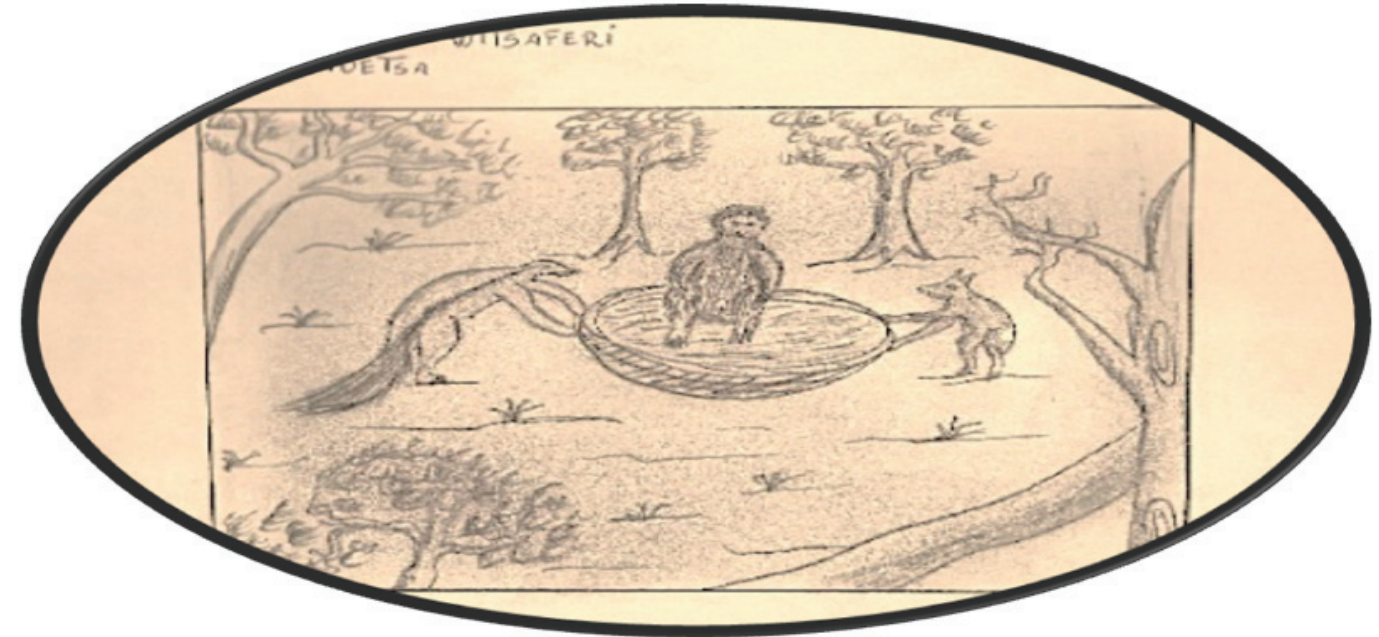

Figure 5: The Animal chief Witháferi, who was carried around in a sieve by his two helpers the anteater and the paca (Drawing by Thiago Aguilar)

may even take its place. Both are important parts of Kuwai's body (the chest and leg).

These two phratries have maintained affinal (marital) relations since at least the 19th Century as oral traditions relate (Wright, 2005). In Hohodene drawings of the cosmos (in Wright, 1998, 2013), the ancestral deities who raised the 2 phratries' ancestors out of the emergence hole at Hipana were related as 'brothers'. In the historical relations of the two phratries, after a long period of warfare which led to near-extinction, they came to be united through marriage, trade and alliance. Affinal relations, however, are marked by competition, treachery, and duplicity, unlike agnatic sibling relations or kin of common descent; sorcery by poisoning is a formidable characteristic of affinal relations, setting them apart in spite of the agnatic ancestrality that ideally brings them together.

Since the drawing discussed in this article was informed by an Hohodene shaman's point of view, several instruments shown are directly related to Hohodene identity more than to any other phratry. Each phratry in Baniwa society consists of a number of sibs, that is, a group of communities who consider themselves to be agnatic siblings, descendants of the same primordial and the same historical ancestor, regardless of whether they can actually trace descent or not. In the case of the Hohodene phratry, there are five sib-ancestors represented in the drawing:

- Aini, the Wasp, ancestor of the Hipatanene sib;

- Mami, Wild Chicken;

- Bubule, a sentinel bird, which represents Kuwai's "kneecap", ancestor of the Herieni sib of Hohodene;

- Atine, the jacamim, a ground bird.

- The Dzathe (toucan) trumpet, Kuwai's thigh, is said to be the bird ancestor of the Piapoco peoples who today live in Venezuela but were, a long time ago, co-residents of the Aiary River with the Hohodene.(see Vidal, 1987) Again, history is re-membered in the ancestral flutes and trumpets. Despite dislocations and migrations, ancestral connections continue in the cultural memory of the phratry.

The category of 'bird-ancestors' is not exhausted by social historical connections, however, for two other pairs of flutes refer to shamanic bird auxiliaries, the Kawawiri and the Idzadapa hawks, both of which have important places as sentinels in the Hohodene drawings of the Universe (see Fig. 6). The first is associated with the wind (kawaale), and the second with rain (iidza). One might sug- 
gest that these shamanic auxiliary bird ancestors occupy an important place as the principal opponents of the primordial monkey species Eenunai- the Chichi and the Ipeku-who were constantly seeking to destroy the Creator. The latter are the Creator's sorcerer enemies, Ipeku being associated with the night, and Chichi with catastrophic thunderstorms. These are kept in check by the shamanic hawks which craftily overcome the monkeys by trickery. The conflicting relations of shamans vs sorcerers is indeed a fundamental dynamic in Hohodene primordial history, as it is in recent history of the disputes between kin and affines.

Two other categories of animal avatars are present in the ancestral body: the ancestral fish and land animals. The suckermouth fish Taali, or surubim, is not only highly prized for its meat but also, as a flute, is considered an emblem of identity for the Baniwa and Kuripako. (see J. Hill 1993, 2013, for more details on the Surubim fish flute and restrictions related to its fabrication) In real life, these fish swim in large numbers at the time of spawning, producing a deep, buzzing noise underwater, comparable to the humming of the Kuwaitrumpets.

In one of the first historical notes about Baniwa ceremonial life, in 1823, the traveller Johann Natterer mentions a great dance of the surubim flutes in the large Baniwa town at Tunui Rapids. The flutes are painted white in intricate designs, ornamented with a white hawk feather, and are explicitly mentioned in the story of the primordial child (purakalinyal) who disobeyed his father's warning not to eat raw fish. The child began 'wasting away', losing all aspects of human-ness, becoming grotesquely other; he heard the buzzing of the white Kuwai, and the white surubim fish Taali. The surubim are, in essence, once kin who were transformed, became other through the treachery of the affines or through their own errors in following the norms of seclusion. (itakerinal)

Another great fish embodied in the trumpets is Iniri, the traira, an enemy of the Creator, which consumed the Creator's younger brother who nevertheless prepared to defend himself with various shamanic items, sat inside the serpent's belly until reaching the mouth of the river where, with the help of the birds, killed and opened the belly of the serpent. The man, practically dead from the poi- son of the fish, made a long return journey home during which, with the sweet remedies of the bee-spirits (called Kuwainyal) and nectar of the fruits, he was able to revive, "exchanging his life for another." Here, the fish ancestor is a predator of humans but was defeated, and pieces of his body became a wide variety of aquatic animals (turtles, various kinds of fish) distributed throughout the downriver world.

This story is the basis for a very powerful shamanic chant to "bring back the heart/souls" of those who have suffered some terrible accident and are unconscious. Sometimes the chant is used as a defense against the White Man's sicknesses (Hill, 2013). Another chant, considered more powerful and secret acts against the sicknesses coming from the original female ancestress, mother of Kuwai, who, after the women lost their power over the sacred flutes, was sent by the Creator on mission to the outside world where she married and became Mother of the Whites. Historical consciousness is deeply embedded in these shamanic chants which work to keep updated the ancient forms. These images are similar to what Pitarch, using the notion of "folds" developed by Guattari, understands as the memory "souls" of Tzeltal Maya. (2013)

\section{Body Adornments and Skins}

Unfortunately, space limitations prevent us from discussing in detail two other aspects of Kuwai's being that merit attention: the adornments attached to each flute or trumpet that identify the instruments with distinctive 'skin covering', or maka, in the forms of the fur, feathers, or fish scales of the ancestral entity. Adornments complete their spirituality; while each is distinctive, all nevertheless share in the essence and powers of their unique source. The coloration, texture, or other outstanding characteristics of these adornments are the basis for their 'spirit-names'. (see Hill 1993; Wright, 1993-4)

Makkim is the concept of the external layer of the Body, the skin covering that is "like a shirt" the Hohodene say, a spirit-shirt. Ornaments and body-painting are associated with emotive states: kerawidzu (caraiuru, red vegetal dye) frequently used 
as body paint, signifying new life, new blood, happiness; feather crowns, such as the owl-feather crown, pupuli-pe, used in funeral rituals refers to the spirit of the dead. The makkim are in a sense like 'spirit-names' (naakuna) in that they highlight a striking feature of the 'person'; however, underneath the makkim is another 'person' altogether (the great Anaconda in Hohodene narrative, for example, is the Creator's father-in-law, a treacherous being whose maka is the Anaconda, but underneath, the person is the ancestral piranha fish, both predatory beings). The Creator likewise has a maka, with which he is able to trick his enemies into thinking he is in one place while he has stepped out of his 'skin' and hidden, in order to slay the unsuspecting enemy.

\section{Connections to Sacred Geography}

The second important aspect mentioned only in passing here refers to the connections of the sacred flutes and trumpets with places, sacred spaces in the "mythscape" (Wright, 2013) of Kuwai. Elsewhere, I have shown how specific geographical features (e.g., a hill, cave, or riverbed) are poetically invoked with metaphoric references to the Body of Kuwai. (1993/4) The chants sung at the pepper blessing (kalidzamal) during initiation re-member the Body (i.e., join together) the parts of which are spread out over an enormous territory in the Northwest Amazon, corresponding to the area of all communities of northern Arawak-language speakers (opposed to communities which do not speak the same language, collectively known as maakunai).

Further, key places focused in the narrative of Kuwai are generally sites with numerous, extraordinary petroglyphs, the placement of boulders which must not be disturbed, powerful rapids and waterfalls, and other features of the ecology that not only re-member the details of the story but continue to be the sources of sustenance and life. Each 'sacred site' is 'blessed' by chanters to protect newly initiated adults from any potential sickness or harm associated with place. Ancestral flutes belonging to specific sibs are kept hidden in streams near the village site (which often are site of historical settlements by the ancestors). This materializes the indelible link between the spiritual "Body of Kuwai" and a notion of ancestral territory that the phratry must guard against any out- side intrusions.

\section{Conclusion}

After the entire process of reproducing his son's Body is complete, the Creator then declares, "people [meaning the new generations] can take these, ...and play them." In other words, the key notion is that of the continuity of the cosmos, Kuwai's body, present everywhere in This World and the Other. This was entrusted to all future generations (walimanal) to care for, remember in rites, and teach to new generations until the end of time. It is easy to understand now how the Hohodene view of their Universe is a musical one.

In this interpretation of Kuwai's Body, we have brought to light the senses of ancestral power contained in the "knowledge" and the "heart/ soul" of the Sun Father, Creator of all life. These may be summarized as follows:

1. Sicknesses, Sorcery, and Remedies: sorcerer animals vs shamanic bird sentinels; the paradoxical duplicity of shamanic power and knowledge;

2. Growth, Fertility, Resistance to Pain: whipping in the rites of exchange (Poodali) or ceremonies of initiation (Kwepan) induces growth at the same time it teaches resistance to the pain of the world; the trumpets are transformative agents of expansive growth;

3. Agnatic sibling ties, transmission of values between ancestors and descendants; the birdsong of ancestral flutes and trumpets represents the ties of "kinship" (ikitchienape) amongst sib-members of a phratry; the birds are the sentinels which guard over potential enemies; they are the preferred helpers of the shamans;

4. the Sacred Body of Kuwai refers to a universal notion of an all-encompassing territory, uniting multiple communities of peoples who speak the same language; the entire set of ancestral instruments constitutes the unity of spirit in and through the instruments and their music, which are always in This World, whether hidden underwater or hidden in a special enclosure in the ritual house of initiation;

6. Cultural Memory and Social History: ancestral instruments that symbolize historically-formed relations of marriage and political alliances; 
7. Replicability of Ancestral Identity by means of musical instruments, the 'heart/soul'(ikaale) of the Sun, a key to the meaning of Kuwai's life, generated by the knowledge (ianheke) of the Creator Father.

The all-encompassing totality of Kuwai's being, the powerful univocality of Kuwai's sounds, the "powerful sound that opened the universe" (/imale-iyu) is unique among Amazonian cosmologies for its capacity to encompass within its spiritual body the multiplicity and diversity of the material world. It is not difficult to understand why such a tremendous power should be kept a secret, too dangerous to handle (like the powerful images of Unkegila of Native North America); a potentially destructive creativity, or equally, a potentially creative destruction (as in regeneration), the spirit of Kuwai is obliged to remain hidden, ashamed (paymaka) of his grotesque features $^{14}$, yet it is the instrument by which all life is reproduced. The remarka ble elaboration of this all-encompassing power demonstrates a truly complex metaphysics which this brief article has merely scratched the surface.

\section{Notes}

1. The research on which this paperis based has been conducted over a period of 3 decades among the Hohodene peoples of the Aiary River in the Northwest Amazon. A Northern Arawak-speaking people, the Hohodene are one of several phratries that comprise a hypothetical 'people' called by outsiders the "Baniwa". This name is not an ethnonym though it has been used by outsiders since early colonization in the 18th Century and today is accepted by the native people as their ethnic identity.

2. Known also as "Yurupary", the general language (trade language of the area), term to refer to the ancestral being whose body gave rise to the sacred flutes and trumpets. Each ethnic group has a different name for this spirit, so missionaries since the 18th Century reduced this cultural diversity to a single battle against the "Yurupary", which actually is a Tupian demiurge of the forest.

3. Sib: a set of communities who consider themselves to be agnatic siblings and descendants of one common Kuwai ancestor, and one common 'historical' ancestor. 'Phratry' is a set of sibs ranked according to the order of emergence of primordial ancestors from the holes of the (now) rapids of $\mathrm{Hi}$ pana on the Aiary River.

4. The numbers of pairs varies with the knowledge of the narrators; Luiz Gomes named 16 pairs, most other narrators named fewer.

5. Shamans say that in Kuwai's village in the Other World, there is a plantation of buriti palmtrees the greatest of which is the "Jaguar Kumale", which is covered with thorns.

6. The Yoopinai spirits have their own shaman, a declared enemy of humans, whose material bodily form is the lizard (dopo).

7. An anaconda impregnates the Creator's wife who betrayed him by having sexual relations with the anaconda; the resulting chaotic situation was the origin of the sickness ifiukali, which people today get from eating raw or rotten fish/meat.

8. Kuwaikere is one of several names referring to the spirit people with whom he lived. There are also Kuwainyai, bee-spirit keepers of potent medicine, their honey that helps "bring back the soul" of an unconscious person.

9. How can a body covered by fur be full of holes at the same time? If we look at photos of a sloth's fur, there are numerous places of discoloration as a result of the fungae, white spots that - from a distance - could very well be seen as 'holes'. It is plausible that these spots are perceived as the 'holes' in Kuwai's body fur.

10. These plants are used in Brazilian popular culture to ward off evil spirits ("Espada de São Jorge", for example)

11. Negative other (Inyai, other; me, neg.)

12. Just as an unripe fruit is difficult to open because its shell is still "wet", so the initiates have to be the right age for the opening of their skin to occur.

13. In the rituals when the sacred flutes and trumpets are played, the adult men and women whip each other often with such force in their strokes that they leave red welts on the back or chest. When it is an initiation ritual, the elders whip the initiates three times, then immediately step down on the initiates' feet while stretching the initiates' torsos by lifting up their arms at their bent elbows. This is to "make the initiates grow 
quickly", the elders say.

14. Compare Overing's brilliant interpretation of the figure of Kuemoi among the Piaroa where she develops the notions of the grotesque and of folly (Overing, 2006). With Kuwai, the ludic aspect can be seen in the childrens' play instruments.

\section{Sources}

Deleuze, Gilles. 1993. The Fold. Leibniz and the Baroque. London. Athlone Press.

Gonzalez-Nanez, Omar. 2007. Las literaturas indigenas maipure-arawakas de los pueblos kurripako, warekena y baniva del estado Amazonas. Fundación editorial el perro y la rana. Caracas.

Hill, Jonathan. 1993. Keepers of the Sacred Chants. Urbana-Chamapaign: University of Illinois Press.

Hill, Jonathan \& J.-P. Chaumeil. 2011. Burst of Breath. Omaha: University of Nebraska Press.

Hugh-Jones, Stephen. 1989. The Palm and the Pleiades. Cambridge: CUP.

Maia, Paulo. 2009. Desequilibrando o convencional: estética e ritual com os Baré do Alto rio Negro. Ph.D. dissertation. PPGAS/Museu Nacional. Rio de Janeiro.

Overing, Joanna. 2006. 'The Backlash to Decolonizing Intellectuality", in Anthropology and Humanism, Vol. 31, No 1, pp. 11-40. Original version in Portuguese: 2004, "A Reação contra a descolonizaçao da intelectualade", Ilha: Revista de Anthropologica, Florianopolis, Brazil.

Pitarch, Pedro. 2013 (English transl.) The Jaguar and the Priest. Austin: University of Texas Press.

Reichel-Dolmatoff, G. 1996. Yurupary. Cambridge: Harvard.

1989. Biological and Social Aspects of the Yurupari Complex of the Vaupes Territory. Jl. of L. Ame. Lore 15(1): 95-135.

Rodrigues de Mello, Glaucia Buratto, 2013. Yurupari. Belem: Paka-Tatu.

Santos-Granero, Fernando. 2009. The Occult Life of Things. Native Amazonian Theories of Materiality and Personhood. Tucson: University of Arizona Press.

Turner, T. 1988. “Ethno-ethnohistory..." In: Hill, J. ed., 1988. Rethinking History and Myth: Indigenous South American Perspectives on the Past. Champaign-Urbana: University of Illinois Press.

Vidal, S. 1999. “Amerindian Groups of Northwest Amazonia: Their Regional System of Politico-Religious Hierarchies." Anthropos 94, pp. 51528.

Vútova, María. 2011. « Cuerpos enfermos, cuerpos humanos. La enfermedad como necesidad entre los arawak del Río Atabo en el Amazonas venezolano ", Nuevo Mundo Mundos Nuevo [En línea], Debates, Puesto en línea el 31 marzo 2011, consultado el 28 mayo 2013. URL: http://nuevomundo.revues.org/61224; DOI : 10.4000/nuevomundo.61224

Wright, Robin M. 2013. Mysteries of the Jaguar Shamans of the Northwest Amazon. Omaha: University of Nebraska Press. 2005. Historia Indigena e do Indigenismo no Alto Rio Negro. Campinas: Mercado de Letras.

1998. Cosmos, Self and History in Baniwa Religion. Austin: University of Texas Press.

1993/4. "Pursuing the

Spirit..." Amerindie, Paris, pp. 1-40.

Xavier Leal, Carlos Cesar. 2008. "A Cidade Grande de Napirikolie os Petroglifos do Icana. ..." M.A. thesis. PPGAS/MN, Rio de Janeiro. 


\section{Appendix: Artwork}

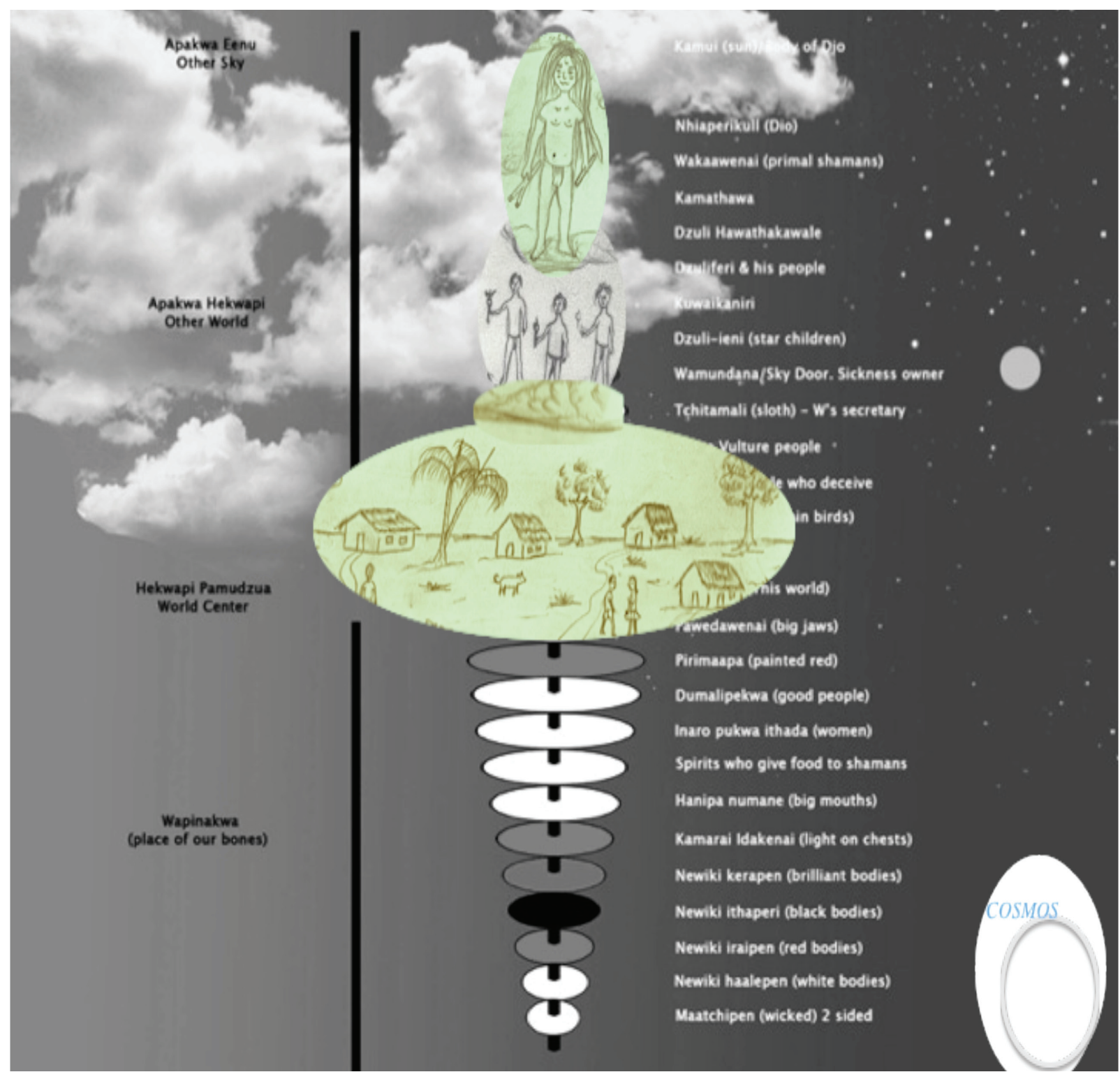

Figure 6: The Other World that the pajés see in their soul journeys. The drawing of the great spirits was done by the same apprentice; the arrangement of layers of the cosmos was done under the direction of the principal jaguar-shaman. Above the human village are the great Spirit of Power Dzuliferi and his three auxiliaries the jaguar- shaman- spirit- others, Dzaui malinyai. 


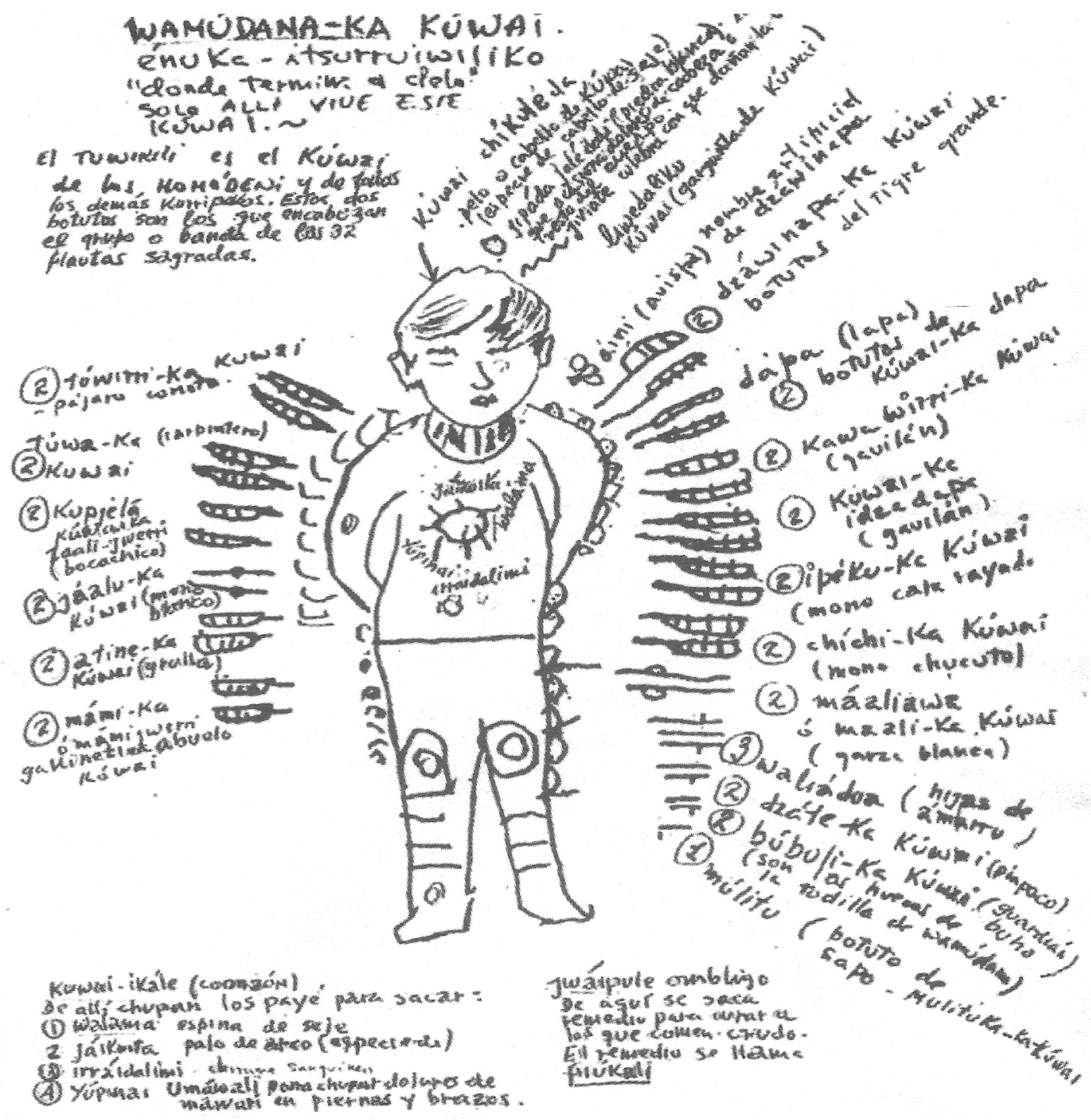

Figure 7: The Body of Kuwai-ka Wamundana Reprinted, with permission, from: Omar Gonzalez-Nanez, 2007. 


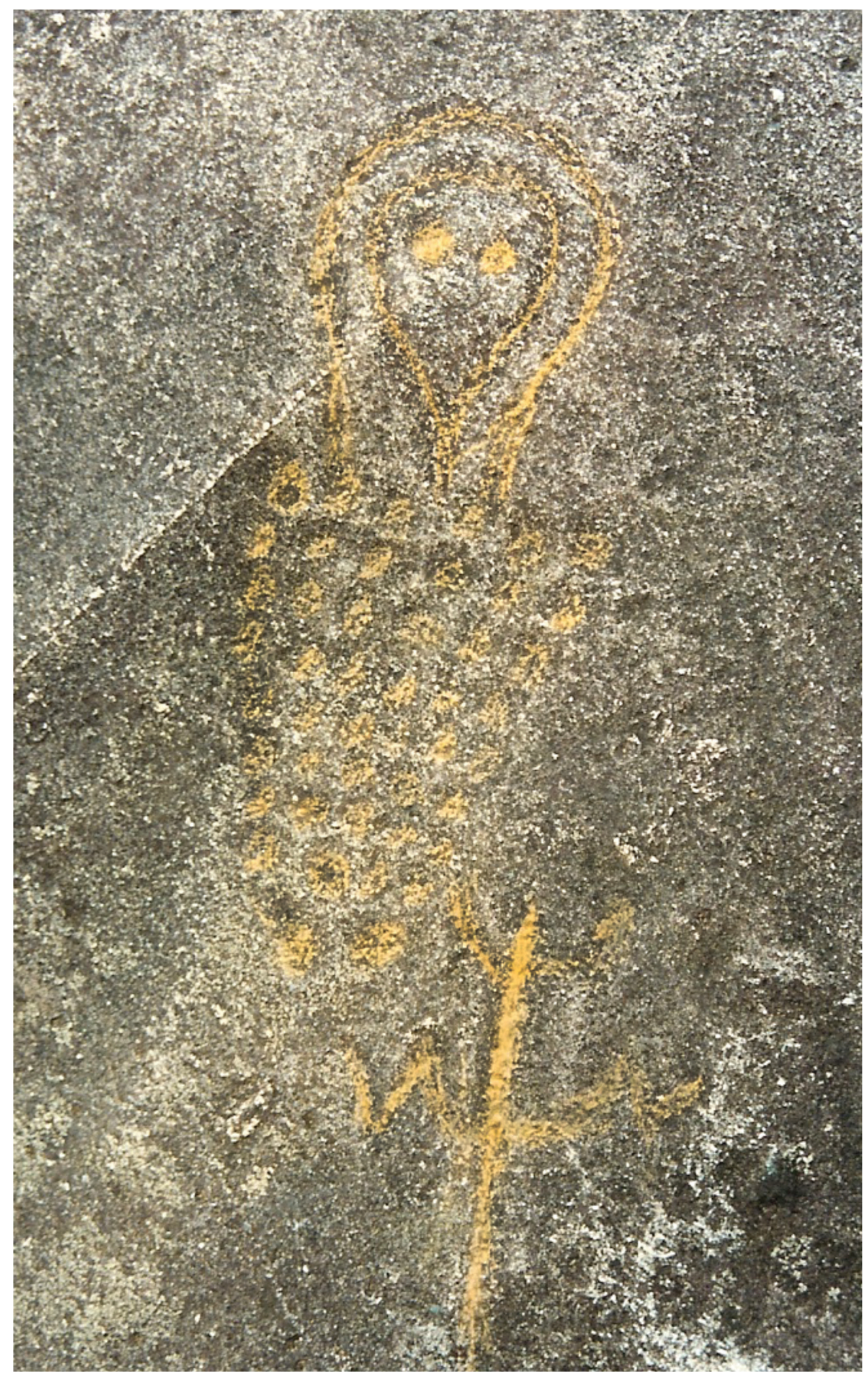

Figure 9: Petroglyph at Hipana: a body full of holes, a head-shape with two eyeholes, whip, and long tail. 


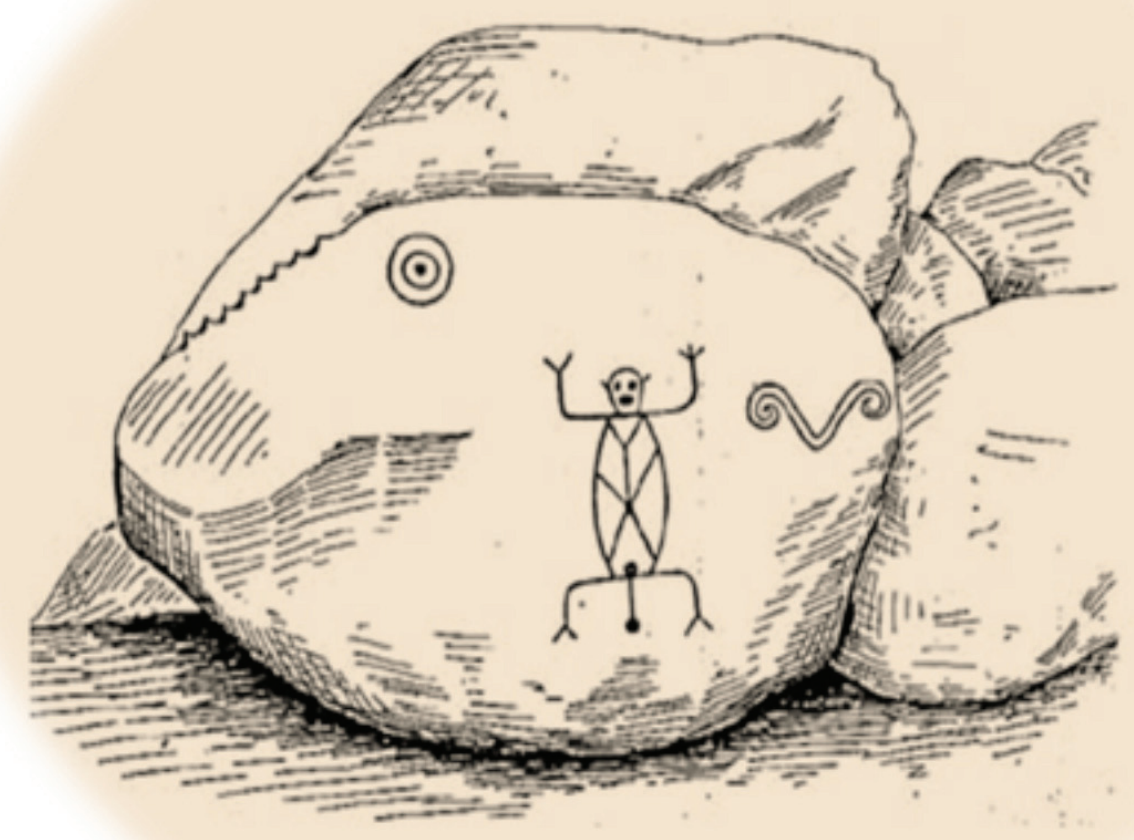

Figure 10: Petroglyph at Enukwa, rapids immediately below Hipana, showing the framework of the body of Kuwai, with two symbols of the sounds emitted from his body. 


\section{Sobre o autor}

Robin M. Wright é Professor Associado especializado em religiões indígenas sul-americanas, Antropologia da Religião e religiões indígenas em geral. Por vinte anos, o Dr. Wright foi professor de Antropologia da Universidade Estadual de Campinas, no Brasil, onde também foi Diretor do Centro de Estudos de Etnologia Indígena. Sua principal pesquisa desde os anos 1970 tem sido no Noroeste Amazônico do Brasil, embora ele tenha feito trabalho na Guatemala e no Nordeste dos EUA (Seis Nações). Publicou amplamente na área das religiões indígenas, histórias indígenas e políticas indigenistas. Entre suas obras mais importantes estão um estudo de três volumes dos povos indígenas e do cristianismo no Brasil; duas etnografias das histórias e religiões dos povos indígenas do Noroeste da Amazônia; uma coleção de narrativas míticas dos índios Baniwa, e um volume coeditado sobre feitiçaria na Amazônia. Publicou mais de cinquenta artigos e capítulos de livros e, desde 1980, tem colaborado com organizações não-governamentais no Brasil e os EUA em prol dos direitos indígenas. 